Available at http://jurnal.stie-aas.ac.id/index.php/jap

Jurnal Akuntansi dan Pajak, 18(02), 2018, 196-203

\title{
Pengaruh Struktur Modal dan Ukuran Perusahaan Terhadap Agency Cost dan Kinerja Perusahaan (Studi Pada Perusahaan Manufaktur Sektor Industri Barang Konsumsi Yang Terdaftar Di Bursa Efek Indonesia)
}

\author{
Dewi Maryam* \\ Sekolah Tinggi Ilmu Ekonomi Indonesia Surabaya, Indonesia \\ *Email korenpondensi: dewimaryam@stiesia.ac.id
}

Recieved: 17-01-2018 | Revised: 25-01-2018 | Accepted: 29-01-2018

\begin{abstract}
Abstrak
Penelitian ini bertujuan untuk menguji pengaruh struktur modal, ukuran perusahaan terhadap agency cost dan kinerja perusahaan. Selain itu, pengaruh tidak langsung antara struktur modal dan ukuran perusahaan terhadap agency cost juga di teliti dalam penelitian ini. Populasi penelitian yang digunakan dalam penelitian ini adalah 18 perusahaan di sektor industri barang konsumsi yang terdaftar di Bursa Efek Indonesia (BEI) dengan periode penelitian tahun 2010-2014. Jumlah sampel penelitian sama seperti dengan jumlah populasi dengan metode sensus. Metode analisis yang digunakan dalam penelitian adalah analisis jalur. Hasil penilitian menunjukkan bahwa terdapat pengaruh signifikan negatif antara ukuran perusahaan terhadap agency cost dan terdapat pengaruh signifikan negatif agency cost terhadap kinerja perusahaan, tidak terdapat pengaruh antara struktur modal terhadap agency cost dan tidak terdapat pengaruh struktur modal terhadap kinerja perusahaan, serta tidak terdapat pengaruh ukuran perusahaan terhadap kinerja perusahaan.
\end{abstract}

Kata Kunci: Struktur Modal, Ukuran Perusahaan, Agency Cost, Kinerja Perusahaan.

\begin{abstract}
This study aims to examine the effect of capital structure, the size of the company to the agency cost and performance of the company. In addition, the indirect influence between capital structure and size of the company to the agency cost is also researched in this study. The study population used in this study were 18 companies in the consumer goods industry sectors listed on the Indonesia Stock Exchange (BEI) in the study period 2010-2014. Number of sample as the number of population by census method. This study analysis method is path analysis using SPSS software. The results of this study show that there is significant influence negatively the size of the company to the agency cost and there is significant influence negatively agency cost to company performance, there is no influence between capital structure to agency cost and there is no influence of capital structure to the company's performance, and there is no effect of firm size on company performance.
\end{abstract}

Keywords: Capital Structure, Company Size, Agency Cost, Company Performance.

\section{Saran sitasi:}

Maryam, D. (2018). Pengaruh Struktur Modal dan Ukuran Perusahaan Terhadap Agency Cost dan Kinerja Perusahaan (Studi Pada Perusahaan Manufaktur Sektor Industri Barang Konsumsi Yang Terdaftar Di Bursa Efek Indonesia). Jurnal Akuntansi dan Pajak, 18(2), $196-203$. doi:http://dx.doi.org/10.29040/jap.v18i2.155

DOI: http://dx.doi.org/10.29040/jap.v18i2.155 


\section{Pendahuluan}

Sektor industri mempunyai peranan penting dalam perekonomian Indonesia. Secara umum sektor ini memberikan kontribusi yang besar dalam pembentukan Produk Domestik Bruto (PDB) nasional dan penerimaan devisa. Sektor industri diyakini sebagai sektor yang dapat memimpin sektor-sektor lain dalam sebuah perekonomian yang maju. Produk industri selalu memiliki tern of trade yang tinggi serta menciptakan nilai tambah yang lebih besar dibandingkan produk-produk lain. Pada umumnya kinerja perusahaan dinilai dari tingkat perolehan laba yang maksimal. Dengan memperoleh laba yang maksimal, perusahaan dapat mempertahankan kelangsungan hidupnya, bertumbuh serta berkembang dalam persaingan usaha yang ketat. Namun, untuk mempertahankan kelangsungan hidup, perusahaan harus memiliki strategi yang terintegrasi dengan baik dan sesuai dengan karakter perusahaan. Manajemen perusahaan juga dituntut untuk dapat mengelola aktiva atau modalnya secara efektif dan efisien. Perusahaan yang mampu memilih strategi dengan tepat serta mampu mengelolanya akan dapat mempertahankan dan mengungguli persaingan dalam pertumbuhan dan perolehan laba serta mampu bertahan dalam siklus kehidupan bisnis dalam jangka waktu yang panjang bagi perusahaan. Ukuran keberhasilan belum cukup hanya dilihat dari besarnya laba yang diperoleh, masalah rentabilitas lebih penting daripada masalah laba. Hal ini dikarenakan laba yang besar belum merupakan ukuran bahwa perusahaan itu telah dapat bekerja secara efisien. Efisiensi baru dapat diketahui tingkat keuntungannya, jika membandingkan laba yang diperoleh dengan kekayaan atau modal yang menghasilkan laba tersebut (Riyanto, 2001:37). Kinerja perusahaan memperlihatkan kemampuan perusahaan untuk memberikan keuntungan dari aset, ekuitas, maupun utang. Kinerja perusahaan merupakan prestasi kerja perusahaan. Salah satu ukuran kinerja perusahaan adalah Return on Equity (ROE). Return on Equity ROE adalah ukuran profitabilitas perusahaan penting yang mengukur pengembalian untuk pemegang saham (Jones, et al, 2009). Di dalam perusahaan terdapat beberapa fungsi, antara lain fungsi pengelolaan dan fungsi kepemilikan. Jensen dan Meckling (1976) mengatakan bahwa pemisahan fungsi pengelolaan dan fungsi kepemilikan sangat rentan dengan agency conflict (konflik kepentingan). Agency conflict terjadi manakala manajer cenderung membuat keputusan yang menguntungkan dirinya daripada kepentingan pemegang saham (Jensen dan Meckling 1976, Myers 1977). Agency conflict dapat menimbulkan agency cost (biaya agensi), yaitu berupa pemberian insentif yang layak kepada manajer serta biaya pengawasan untuk mencegah hazard. Agency conflict dapat terjadi antara pemegang saham dengan manajer dan pemegang saham dengan kreditur (Husnan, 2001).

Perusahaan dapat didanai dengan utang dan ekuitas. Komposisi penggunaan utang dan ekuitas ini tergambar dalam struktur modal. Penggunaan utang diistilahkan dengan financial leverage (pengungkit keuangan). Utang (debt) yang dimaksud adalah utang untuk pendanaan perusahaan yang tidak selalu sama dengan kewajiban (liabilities) dan tidak sama dengan tagihan (payable). Utang menimbulkan beban bunga yang dapat menghemat pajak. Artinya beban bunga dapat dikurangkan dari pendapatan sehingga laba sebelum pajak menjadi lebih kecil dan akibatnya pajak semakin kecil. Sedangkan jika pendanaan menggunakan ekuitas, maka tidak terdapat beban yang dapat mengurangi pajak perusahaan.

Dalam literatur finance, Jensen dan Meckling (1976) adalah yang pertama menghubungkan agency cost dengan utang dalam struktur modal. Penggunaan utang dalam struktur modal dapat mencegah pengeluaran perusahaan yang tidak penting dan memberi dorongan pada manajer untuk mengoperasikan perusahaan dengan lebih efisien. Hal tersebut menyebabkan agency cost berkurang. Penggunaan utang yang tinggi dalam struktur modal mungkin mempengaruhi perilaku manajer. Jika keadaan baik, manajer akan menggunakan aliran kas untuk bonus atau pengeluaran- 
pengeluaran tidak perlu yang disebut agency cost. Tetapi ancaman kebangkrutan karena utang yang tinggi dapat mengurangi pengeluaran yang tidak penting sehingga akan meningkatkan free cash flow (aliran kas bebas). Dengan demikian diharapkan utang tersebut dapat mengurangi agency cost.Penelitian ini diharapkan memiliki banyak implikasi penting bagi manajer, pemegang saham, dan akademisi tertarik pada bagaimana perusahaan-perusahaan menggunakan pendanaan utang dan penggunaan aktiva atau aset perusahaan sebagai cara meminimalkan agency cost dengan tujuan akhir adalah memaksimalkan kinerja perusahaan.

\section{Metode Penelitian}

Penelitian ini adalah penelitian eksplanatori. Penelitian eksplanatori (explanatory research) yang bermaksud untuk menjelaskan hubungan variabel yang akan diteliti adalah pengaruh variabel struktur modal, ukuran perusahaan terhadap agency cost dan kinerja perusahaan pada perusahaan manufaktur sektor industri barang konsumsi yang terdaftar di Bursa Efek Indonesia melalui pengujian hipotesis sekaligus melakukan eksplanasi atau penjelasan. Penentuan jenis penelitian eksplanatoris ini sesuai dengan pengertian yang dijelaskan oleh (Sekaran, 2006) yaitu penelitian yang dilakukan dengan maksud penjelasan (eksplanatory and confirmatory), yang memberikan penjelasan kausal atau hubungan antar variabel melalui pengujian hipotesis. Metode analisis data yang digunakan dalam penelitian ini adalah analisis jalur (path analysis) untuk menganalisa pola hubungan antar variabel dengan tujuan untuk mengetahui pengaruh tidak langsung seperangkat variabel bebas terhadap variable terikat yang dimediasi oleh variabel intervening, dari populasi yang berjumlah 37 didapat sampel sebesar 18 perusahaan. Data diambil dari caporal keuangan perusahaan dan Indonesian Capital Market Directory (ICMD) perusahaan manufaktur sektor industri barang konsumsi periode tahun 20102014 dan lampiran-lampiran laporan keuangan yang berkaitan dengan penelitian.Keseluruhan tahap analisis data dilakukan dengan menggunakan bantuan program linieritas SPSS (Statistical Package for the Social Sciences) for Windows versi 22.0. dan Smart Modelling PLS versi 2.0.

Jenis data yang digunakan dalam penelitian ini adalah data sekunder. Data sekunder merupakan data yang diperoleh dalam bentuk yang sudah jadi, berupa publikasi dan bersifat dokumenter. Jenis data sekunder yang digunakan dalam penelitian diperoleh dari Indonesian Capital Market Directory (ICMD) dan laporan tahunan perusahaan manufaktur sektor industri barang konsumsi tahun 2010-2014 yang diperoleh dari Bursa Efek Indonesia di Universitas Brawijaya. Adapun tahapan pengumpulan data yang dilakukan adalah sebagai berikut : Tahap pertama, dilakukan dengan mengumpulkan data sekunder yang diperlukan, yakni laporan keuangan perusahaan dan Indonesian Capital Market Directory (ICMD) perusahaan manufaktur sektor industri barang konsumsi dan lampiran-lampiran laporan keuangan yang berkaitan dengan penelitian. Tahap kedua, dilakukan dengan menghitung data-data yang dibutuhkan variabel-variabel antara lain struktur modal, ukuran perusahaan, agency cost, dan kinerja perusahaan yang diambil dari laporan keuangan perusahaan dan Indonesian Capital Market Directory (ICMD) dan kemudian dilakukan analisis.

\section{Hasil dan Pembahasan}

Perhitungan koefisien path pada penelitian ini menggunakan analisis path dengan melihat pengaruh secara simultan dan parsial pada masing-masing persamaan. Adapun hasil analisis sebagaimana pada Tabel 1.

Berdasarkan Tabel 1, nilai $\mathrm{R}$ Square menunjukkan nilai sebesar 0,383 atau $38,3 \%$. Artinya bahwa Y1 dipengaruhi oleh X1 dan X2 sebesar 38,3\%, Sedangkan sisanya sebesar $61,7 \%$ dipengaruhi oleh variabel di luar variabel bebas yang diteliti atau variabel yang tidak dijelaskan dalam penelitian ini. Berdasarkan pengujian simultan (uji F) dapat dilihat bahwa $\mathrm{F}$ hitung sebesar 27,006 dan signifikan sebesar 0,000. Maka kesimpulan yang diambil adalah 
Jurnal Akuntansi dan Pajak, 18(02), 2018, 199

Tabel 1. Hasil Analisis Path X1 dan X2 terhadap Y1

\begin{tabular}{ccccc}
\hline Variabel & $\begin{array}{c}\text { Standart } \\
\text { coefficient } \\
\text { beta }\end{array}$ & T hitung & P value & Keterangan \\
\hline X1 (Struktur Modal) & 0,093 & 1,084 & 0,281 & Tidak signifikan \\
X2 (Ukuran Perusahaan) & $-0,596$ & $-6,966$ & 0,000 & Signifikan \\
\hline T tabel & $=1,9995$ & & & \\
Df & $=69$ & & & \\
R Square & $=0,383$ & & & \\
F hitung & $=27,006$ & & & \\
Signifikansi & $=0,000$ & &
\end{tabular}

Tabel 2. Hasil Analisis Path Pengaruh X1 ,X2, Y1 terhadap Y2

\begin{tabular}{ccccc}
\hline Variabel & $\begin{array}{c}\text { Standart } \\
\text { coefficient beta }\end{array}$ & T hitung & P value & Keterangan \\
\hline X1 (Struktur Modal) & $-0,120$ & $-1,571$ & 0,120 & Tidak signifikan \\
X2 (Ukuran Perusahaan) & 0,142 & 1,508 & 0,135 & Tidak signifikan \\
\hline Y1 (Agency cost) & $-0,593$ & $-6,251$ & 0,000 & Signifikan \\
\hline T tabel & $=1,9995$ & & & \\
Df & $=68$ & & & \\
R Square & $=0,523$ & & & \\
F hitung & $=31,443$ & &
\end{tabular}

signifikansi $(0,000)$ lebih kecil dari 5\% sehingga diputuskan bahwa terdapat pengaruh bersamasama pada variabel X1 dan X2 terhadap Y1. Persamaan regresi standardize 1:

$\mathrm{Y} 1_{\text {Agency cost }}=0,093 \mathrm{X} 1_{\text {Struktur Modal }}+-0,596$ $\mathrm{X} 2_{\text {Ukuran Perusahaan }}+\varepsilon_{1}$.

Dari nilai $t_{\text {hitung }}$ menunjukkan bahwa variabel $\mathrm{X} 1$ memiliki nilai $\mathrm{t}_{\text {hitung }}$ sebesar 1,084 dengan signifikansi sebesar 0,281. Karena signifikansi t lebih besar dari $\alpha(0,281>0,05)$ maka sudah cukup bukti untuk menyatakan variabel X1 tidak berpengaruh terhadap $Y 1$. Dari nilai $t_{\text {hitung }}$ menunjukkan bahwa variabel $\mathrm{X} 2$ memiliki nilai $t_{\text {hitung }}$ sebesar -6,966 dengan signifikansi sebesar 0,000 . Karena signifkansi t lebih kecil dari $\alpha$ $(0,000<0,05)$ maka sudah cukup bukti untuk menyatakan variabel X2 berpengaruh signifikan terhadap Y1. Koefisien negatif menunjukkan bahwa setiap 1 kenaikan ukuran perusahaan maka akan menurunkan agency cost sebesar 0,596 .

Berdasarkan Tabel 2, nilai $\mathrm{R}$ Square menunjukkan nilai sebesar 0,523 atau $52,3 \%$. Artinya bahwa Y2 dipengaruhi sebesar 52,3\% oleh X1, X2 dan Y1 Sedangkan sisanya sebesar
47,7\% dipengaruhi oleh variabel lain di luar variabel bebas yang teliti atau variabel lain yang tidak terdeteksi di penelitian ini. Berdasarkan pengujian simultan (uji F) dapat dilihat bahwa $\mathrm{F}$ hitung sebesar 31,443 dan signifikan sebesar 0,000. Maka kesimpulan yang diambil adalah signifikansi $(0,000)$ lebih kecil dari 5\% sehingga diputuskan bahwa terdapat pengaruh bersamasama padavariabel X1, X2 dan Y1 terhadap Y2. Persamaan regresi standardize 2:

$\mathrm{Y} 2_{\mathrm{ROE}}=-0,120 \mathrm{X} 1_{\text {Leverage }}+0,142 \mathrm{X} 2_{\text {Total aktiva }}$ $0,593 \mathrm{Y} 1_{\text {Agency cost }}+\varepsilon_{2}$.

Dari nilai $t_{\text {hitung menunjukkan bahwa }}$ variabelX1 memiliki nilai $t_{\text {hitung }}$ sebesar $-1,571$ dengan signifikansi sebesar 0,120. Karena signifikansi t lebih besar dari $\alpha(0,120>0,05)$ maka sudah cukup bukti untuk menyatakan variabel X1 tidak berpengaruh terhadap Y2.Dari nilai $t_{\text {hitung menunjukkan bahwa variabelX2 }}$ memiliki nilai $t_{\text {hitung }}$ sebesar 1,508 dengan signifikansi sebesar 0,135. Karena signifikansi t lebih besar dari $\alpha(0,135>0,05)$ maka sudah cukup bukti untuk menyatakan variabel X2 tidak berpengaruh terhadap Y2.Dari nilai $t_{\text {hitung }}$ menunjukkan bahwa variabel Y1 memiliki nilai 


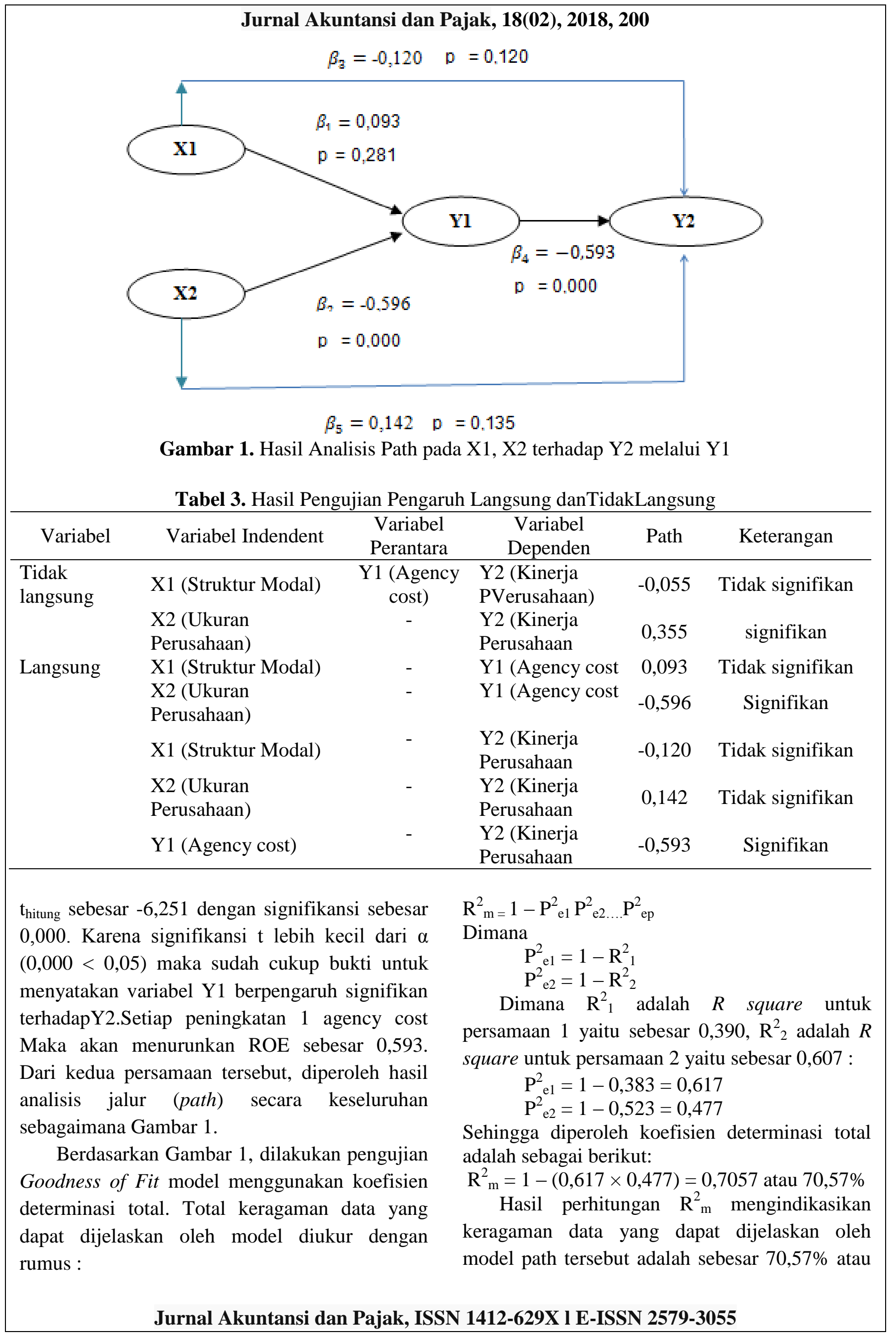


dengan kata lain informasi yang terkandung dalam data $70,57 \%$ dapat dijelaskan oleh model tersebut. Sedangkan 29,43\% keragaman sisanya dijelaskan oleh variabel lain (yang belum terdapat di dalam model).

Penelitian ini mengusulkan model hubungan langsung maupun tidak langsung variabel struktur modal, ukuran perusahaan, agency cost, dan kinerja perusahaan pada perusahaan manufaktur sektor industri barang konsumsi di Bursa Efek Indonesia. Berdasarkan hasil analisis deskripsi dan pengujian model ataupun pengujian hipotesis yang telah dilakukan, berikutnya akan dibahas relevansinya terhadap teori yang terkait, penelitian terdahulu dan fakta empiris (teramati) dan diharapkan dapat mengungkapkan adanya temuan-temuan.

Hipotesis 1, hasil penelitian menemukan bahwa pengaruh langsung antara struktur modal terhadap agency costmerupakan pengaruhyang tidak signifikan. Hal ini dikarenakan pada hasil analisis statistik deskriptif diketahui agency cost lebih tinggi nilainya daripada struktur modal, sehingga mengindikasikan bahwa perusahaan dalam menjalankan operasionalnya lebih menggunakan beban-beban discreationary (beban operasi, beban non operasi, beban bunga, gaji dan upah)terhadap penjualan bersih daripada menggunakan utang. Oleh karena itu nilai $\mathrm{R}$ square antara struktur modal terhadap agency cost kecil, menunjukkan bahwa agency cost belum mampu mempengaruhi struktur modal. Hal ini disebabkan perusahaan manufaktur sektor industri barang konsumsi lebih banyak menggunakan modal sendiri daripada penggunaan utang. Hasil penelitian ini sejalan dengan penelitian Immanuella (2014) bahwa struktur modal tidak berpengaruh terhadap agency cost, namun tidak sejalan dengan penelitian Fachrudin (2011) dan penelitian Campbell et al (2003) bahwa struktur modal berpengaruh signifikan terhadap agency cost.

Hipotesis 2, hasil penelitian menemukan bahwa pengaruh langsung antara ukuran perusahaan terhadap agency costdanmerupakan pengaruh signifikan. Hal ini di dukung dengan hasil analisis statistik deskriptif yang terlihat bahwa nilai ukuran perusahaan dominan tinggi, maka dapat disimpulkan bahwa perusahaan menggunakan total aktiva (aset) yang besar sehingga mengurangi beban discreationary.Hasil uji ini sesuai dengan temuan Lin (2006). Penelitian ini juga sesuai dengan Zhang dan Li (2008) yang menemukan pengaruh signifikan negatif ukuran perusahaan terhadap agency cost. Ukuran perusahaan yang besar membutuhkan sedikit beban discretionary.

Hipotesis 3, Hasil penelitian ini menunjukkan pengaruh langsung antara struktur modal terhadap kinerja perusahaan merupakan pengaruh yang tidak signifikan. Terlihat dari hasil statistik deskriptif diketahui bahwa struktur modal dengan nilai yang lebih rendah daripada kinerja perusahaan. Hal ini mengindikasikan bahwa perusahan menggunakan lebih banyak modal sendiri daripada utang, sehingga perusahaan tidak dapat mengurangi beban bunga dan menyebabkan naiknya pajak yang dapat menurunkan kinerja perusahaan. Penelitian ini tidak sejalan dengan teori Jones et al. (2009) yang mengatakan bahwa struktur modaldapat mempengaruhi kinerja perusahaan, hal ini terjadi karena pembiayaan dengan utang menimbulkan beban bunga yang tetap harus dibayar. Penelitian ini juga tidak dapat menunjukkan bahwa struktur modalmenurunkan imbal hasil kepada pemegang saham. Berarti dana dari utang belum digunakan dengan baik sehingga akan berimbas pada penurunan laba.

Hipotesis 4, hasil menemukan bahwa pengaruh langsung antara ukuran perusahaan terhadap kinerja perusahaan merupakan pengaruh tidak signifikan. Dari hasil analisis statistik deskriptif terlihat ukuran perusahaan nilainya lebih rendah daripada kinerja perusahaan. Hal ini menunjukkan bahwa tidak semua perusahaan besar mempunyai total aktiva (aset) yang besar, sehingga perusahaan lebih mengandalkan modal untuk meningkatkan laba perusahaan. Penelitian ini tidak sejalan dengan temuan Gray dan Larson (2008) yang mengungkapkan bahwa perusahaan besar akan 
mengungkapkan informasi lebih banyak daripada perusahaan kecil. Hasil penelitian ini juga tidak sesuai penelitian dari Immanuella (2014) yang menyatakan bahwa perusahaan dengan total asset yang besar mencerminkan kemapanan perusahaan.

Hipotesis 5, hasil penelitian menunjukkan bahwa agency cost berpengaruh signifikan terhadap kinerja perusahaan. Hal ini dikarenakan dari hasil analisis statistik deskriptif diketahui bahwa agency cost dengan rata-rata perusahaan yang lebih besar daripada kinerja perusahaan, dimana nilai ini mampu meningkatkan kinerja perusahaan. Hasil penelitian ini sejalan dengan temuan Lin (2006) yang mengemukakan bahwa agency cost merupakan biaya yang harus ditanggung oleh pemegang saham agar manajemen mengelola perusahaan secara efisien untuk meningkatkan nilai atau kekayaan pemegang saham. Hasil penelitian ini juga sesuai dengan Kim dan Lee (2003) yang menemukan hubungan erat antara agency problem dengan kinerja perusahaan, artinya beban perusahaan mempengaruhi kinerja perusahaan. Hasil penelitian ini juga sejalan dengan Wright et al. (2009) yang menemukan bahwa agency cost berpengaruh negatif dan signifikan terhadap kinerja perusahaan, artinya bila agency cost dibiarkan membengkak, maka hal tersebut dapat mengurangi pencapaian keuntungan kompetitif yang berdampak negatif terhadap kinerja.

Dari hasil pengaruh tidak langsung di Tabel 3 diketahui bahwa agency cost mampu memoderasi ukuran perusahaan terhadap kinerja perusahaan. Namun, ketika ukuran perusahaan sendiri yang mempengaruhi kinerja perusahaan hasilnya tidak signifikan. Hal ini di sebabkan agency cost merupakan kontrol dari pihak manajerial, karena dengan fungsi pengawasan dan kontrol menggunakan discreationary expense pada penjualan bersih akan berimbas pada peningkatan kinerja perusahaan.

\section{Kesimpulan}

Melalui hasil pengujian hipotesis dan pembahasan hasil penelitian yang telah dilakukan sebelumnya, maka dapat ditarik beberapa kesimpulan. Pengaruh struktur modal terhadap agency costmerupakan pengaruh tidak signifikan, sedangkan pengaruh antara ukuran perusahaan terhadap agency costmerupakan pengaruh signifikan. Hal ini mengindikasikan bahwa perusahaan tidak menggunakan utang dalam jumlah besar tetapi lebih menggunakan aset atau aktiva perusahaan dalam menjalankan operasional perusahaan agar dapat mengungkapkan informasi yang lebih luas untuk mengurangi agency cost. Pengaruh struktur modal terhadap kinerja perusahaan merupakan pengaruh tidak signifikan, begitu juga dengan pengaruh antara ukuran perusahaan dan kinerja perusahaan tidak signifikan. Hal ini mengindikasikan bahwa struktur modal tidak dapat menurunkan imbal hasil kepada pemegang saham, berarti dana dari utang belum digunakan dengan baik sehingga menurunkan laba dan perusahaan dengan aset yang besar tidak selalu dapat menghasilkan keuntungan yang besar apabila tidak diikuti dengan hasil dari aktivitas operasionalnya yang baik. Pengaruh antara agency cost terhadap kinerja perusahaan diperoleh merupakan pengaruh signifikan.

Koefisien path yang bernilai negatif menunjukkan bahwa semakin meningkat agency cost, maka akan terdapat kecenderungan bahwa kinerja perusahaan akan semakin meningkat. Sebaliknya, semakin meningkat agency cost, maka akan terdapat kecenderungan bahwa kinerja perusahaan akan semakin menurun. Pengaruh tidak langsung antara struktur modal terhadap kinerja perusahaan melalui agency cost diperoleh dari hasil kali pengaruh langsung antara struktur modal terhadap agency cost dan agency cost terhadap kinerja perusahaan. Karena pengaruh langsung antara struktur modal terhadap agency costtidak signifikan dan pengaruh langsung antara agency cost terhadap kinerja perusahaan signifikan, maka pengaruh tidak langsung struktur modal terhadap kinerja perusahaan melalui agency cost artinya agency cost sebagai intervening (perantara) tidak signifikan.Pengaruh tidak langsung antara ukuran perusahaan terhadap kinerja perusahaan 
melalui agency cost diperoleh dari hasil kali pengaruh langsung antara ukuran perusahaan terhadap agency cost dan pengaruh langsung antara agency cost terhadap kinerja perusahaan. Karena pengaruh langsung antara ukuran perusahaan terhadap agency cost signifikan dan pengaruh langsung antara agency cost terhadap kinerja perusahaan signifikan, maka pengaruh tidak langsung ukuran perusahaan terhadap kinerja perusahaan melalui agency cost artinya agency cost sebagai intervening (perantara) signifikan.

\section{Ucapan Terimakasih}

Penulis ingin mengucapkan terimakasih kepada Sekolah Tinggi Ilmu Ekonomi Indonesia Surabaya yang telah mendukung selesainya penelitian ini.

\section{Daftar Pustaka}

Campbell R. Harveya,b, Karl V. Linsc, Andrew H. Roperd. (2003). The effect of capital structure when expected agencycosts are extreme.Journal of Financial Economics, Vol 74, Page 3-30.

Fachrudin, Khaira Amalia. (2011). Analisis Pengaruh Struktur Modal, Ukuran Perusahaan, dan Agency Cost terhadap Kinerja Perusahaan, JurnalAkuntansi dan keuangan, vol 13, no.1.

Gray, C., and Larson, E. (2008). Project Management - the Managerial Process, 4th Edition. McGraw Hill.

Husnan, Suad. (2001). Corporate Governance dan Keputusan Pendanaan: Perbandingan Kinerja Pemegang Saham Pengendali Perusahaan Multinasional dan Bukan Multinasional. Jurnal Riset-Akuntansi, Manajemen, Ekonomi, PPAM STIE Yo, 1(1), hal. 1-12.

Immanuella, Intan. (2014). Pengaruh Kepemilikan Manajerial, Struktur Modal, Ukuran Perusahaan, dan Agency Cost sebagai Variabel Intervening terhadap Kinerja Perusahaan pada Perusahaan Manufaktur yang Terdaftar di BEI,
JurnalAkuntansi dan keuangan, vol 112, no.1.

Jensen, M. C., and Meckling, W.H. (1976). Theory of the Firm : Managerial Behavior, Agency Costs and Ownership Structure. Journal of Financial Economics. Vol 3, pp. 305-360. http://papers.ssrn.com

Jones, Charles P., Siddharta Utama, Budi Frensidy, Irwan Adi Ekaputra, dan Rachman Untung Budiman. (2009). Investment Analysis and Management (An Indonesian Adaptation), Wiley, Salemba Empat. Jakarta.

Kim, Byungmo. and Lee, Inmoo,. (2003). Agency Problem and Performance of Korean Companies during the Asian Financial Crisis: Chaebol vs non Chaebol Firms. Pacific Basin Finanve Journal.

Lin, Kun Lin. (2006). Study on Related Party Transaction with Mainland China in Taiwan Enterprises, Dissertation, Universitas Guo Li Cheng Gong, China.

Myers, S. (1977). Determinants of corporate borrowing. Journal of Financial Economics. Vol : 5. Pp 147-175.

Riyanto, Bambang. (2001). Dasar-Dasar Pembelanjaan Perusahaan, Edisi Keempat, Cetakan Ketujuh. BPFE. Yogyakarta.

Sekaran, Uma. (2006), Metodologi Penelitian untuk Bisnis, Edisi 4, Buku 1, Salemba Empat. Jakarta.

Sekaran,Uma. (2006), Metodologi Penelitian untuk Bisnis, Edisi 4, Buku 2, Salemba Empat. Jakarta.

Wright, Peter, Mark Kroll, Ananda Mukhreji, Michael L. Pettus. (2009). Do the Contingencies of External Monitoring, Ownership Incentives, or Free Cash Flow Explain Opposing Firm Performance Expectations?.Journal Management Governance. Vol13, pp. 215-243.

Zhang, He,.and Li, Steven. (2008). The Impact of Capital Structure on Agency Cost: Evidence from UK Public Companies. Journal of Economic Literature. 